\title{
Prediction of low flow at ungauged Sites
}

\author{
Puteri Shazlia Rosman \\ Faculty of Engineering Technology, Universiti Malaysia Pahang, Lebuhraya Tun Razak, 26300 Gambang, \\ Kuantan, Pahang Malaysia \\ Email: putrishazlia@ump.edu.my
}

\begin{abstract}
Low flow prediction at the ungauged site area is important for planning the development water resources management especially that related to power supply or navigation, reservoir design, irrigation, drinking water supply and aquaculture farming. However, the sequent data collection must be collected to able to see the pattern of low flow in future. The purpose of the study to determine low flow at various locations within the tributaries of Sg. Sawak and Sg. Rompin catchment area. Low flow was estimated using 7Q10 equation (estimate the lowest 7 day average flow that occurred on average once every 10 years. The result indicate the 7Q10 in Sg Sawak Catchment and Sg. Pontian Catchment were $0.0179 \mathrm{~m}^{3} / \mathrm{s}$ in and $0.0067 \mathrm{~m}^{3} / \mathrm{s}$ respectively.
\end{abstract}

Indexed Terms- Water flow, water resources, catchment area

\section{INTRODUCTION}

Many areas all over the world experiencing flood unpredicted as the high water levels increases due several consequences. Improper development management, unplanned and illegal drainage piping, untreated wastewater of livestock and other agricultural also the illegal industry rises up the pollution into the river. Many communities in the world depend on the availability and purified water as their water supply and transportation. It is important that the period of low flow are critical for managing their water resources [1]. Other, than that river low flows can lead to severe consequences in water quality and river ecological status [2]. To balanced water supply in order to meet the supply water demand, it is important to understand the function and role of dams to level out the fluctuations of high and low flow [3]. The changes of the land uses will results in changing the way of water interacts with the landscape that will affect the water availability in the river. Pollution in water bodies can be derived from numerous sources of pollution [4].

The study become more important during low flows as the different water uses arise, especially between instream water use and water abstraction demand that puts the pressure on rivers [5]. The river, swamps, reservoir and the estuary water quality would be adversely affected by the numerous field drains and river tributaries that transport waste and pollutants to the water bodies. The situation could be aggravated during dry season or when the flow in the river is at low level (point source) and during wet season or when there is frequent storm (non-point source).

According to the World Meteorological Organization the meaning of low flow is the "flow of water in a stream during prolonged dry weather. " Low flows typically aggravate the effects of water pollution. Dilution is the primary mechanism by which the concentrations of contaminants (e.g., copper, lead) discharged from industrial facilities and other point and some non-point sources are reduced. Less water available to dilute effluent loading during a low flow event causes resulting in higher in-stream concentration of pollutants [6].

The warming effect of the sun have greater impacts on stream water temperatures during low flow periods that effects of these factors could be additional stressors on aquatic life. The analysis of the study using the 7Q10 as the model is widely used throughout the world. The 7Q10 means "sevenday, consecutive low flow with a ten year return frequency; [or] the lowest stream flow for seven 
consecutive days that would be expected to occur one in ten years [7-8]. The most common use design flow statistics such as the 7Q10 (the lowest 7-day average flow that occurs on average once every 10 years) to define low flow for the purpose of setting permit discharge limits [9].

Low Flow frequency and calculation analysis are easy to handle for long time gauged catchments. However for low flow index has to be inferred using neighbouring gauged catchment data for estimation of ungauged catchment [10].

The estimation of low flows in ungauged river catchments, Smakhtin (2001) [11] reviewed all possible techniques and the most widely used are cited regional regression approach. Other methods use regional prediction curves, time-series simulation or spatial interpolation.

Low flow of natural streams depends on the recharge from groundwater to the stream. The rate of recharge from groundwater to streams depends on the catchment area, geologic condition, land use and mean annual rainfall of the catchment area. It also depends on the hydraulic gradient toward the stream and hydraulic conductivities of the aquifer to the stream.

The magnitude and frequency of low flow discharges is important for water supply planning, waste load allocation, storage facility design, and irrigation, recreational and aquatic life.

Low flow has three main characteristics that are duration, magnitude and frequency of occurrence. Duration it is reflect the tolerance of the user to periods of water deficits. Second is magnitude able to determine the amount of water at low flow for specific duration and lastly frequency of occurrence; the frequency of occurrence of low flow reflects the risk associated with the failure of water supply.

The aim of this study is to determine low flow at various locations within the study of $\mathrm{Sg}$. Sawak and Sg. Rompin catchment area.

\section{MATERIAL AND METHODS}

\subsection{Study Area}

The study area is located within Sg. Pontian and Sg. Sawak Catchment. The area of oil palm plantation area is about $8 \mathrm{~km}^{2}$. The outlet of Sg Pontian catchment area is about $11 \mathrm{~km}^{2}$ while the outlet of Sg Sawak catchment area is about $21.7 \mathrm{~km}^{2}$.

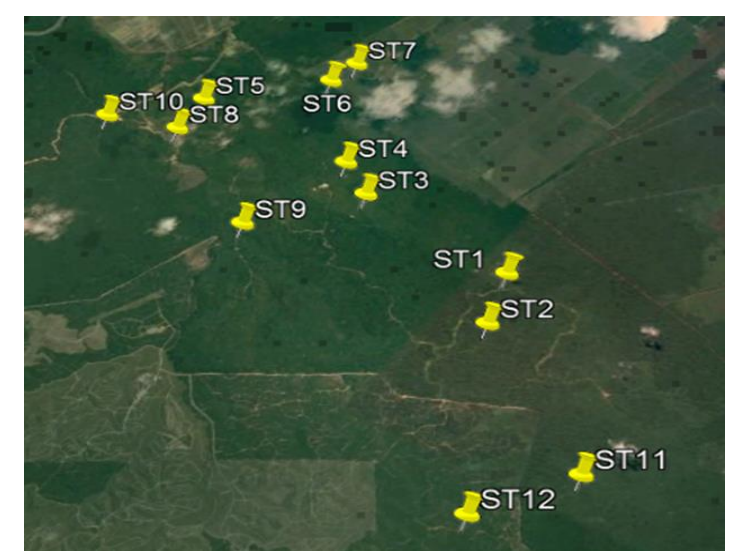

Figure 1: Sg. Sawak and Sg. Pontian Sample Station

\subsection{Low flow index}

In this study, the mean annual minimum of 7- day average flows (MAM7) was used as the index to characterise low flow. The benefit of using the MAM7 is that it can eliminate day to day variations 
and allows analyses to be less sensitive to measurement errors. According to Smakhtin, (2001) [11] the 7 day low flow is not different from 1 day low flows.

\section{RESULT AND DISCUSSION}

\subsection{Low Flow Estimation for Ungauged Site at Ungauged Stream}

The purpose of applying un-gauged method to gauged catchments is to test the reliability of the result obtained from the un-gauged method when compared to the result obtained from observed low flow data. The parameters of the regional frequency low flow curves, and the regional $\frac{Q_{D, T}}{M A M}$ values for various Average Recurrence Interval (ARI).

\subsection{Mean Annual Minimum Flow (MAM)}

To obtain low flow for various consecutive numbers of days and various ARI, the MAM has to be correlated to the catchment characteristics. The regional MAM equation is shown below;

$\mathrm{MAM}=\mathrm{a}(\mathrm{X} 1) \mathrm{b} 1(\mathrm{X} 2) \mathrm{b} 2 \ldots . .(\mathrm{Xn}) \mathrm{bn}$

$\mathrm{X} 1, \mathrm{X} 2, \ldots \ldots \mathrm{Xn}$ are catchment characteristics while $\mathrm{b} 1, \mathrm{~b} 2, \ldots \ldots \mathrm{bn}$ are constants to be estimated.

\subsection{Low Flow Estimation}

The low flow estimation for the un-gaged site are presented as average values to represent both wet and dry season condition, in which $\mathrm{D}$ is number of day and $\mathrm{T}$ is recurrence interval.

\subsection{MAM flow equation}

In the developing the equation, two variables data were used. The variables are the catchment area (AREA) and the Mean Annual catchment Rainfall (MAR). The MAR data shall be adopted from the rainfall stations located near and within the river basin.

The general MAM flow equation as shown below,

$$
M A M=a(A R E A)^{b 1}(M A R)^{b 2}
$$

Where AREA is the catchment area in km2; MAR is the mean annual rainfall; a, b1, b2 are coefficients. Values of coefficient $\mathrm{a} 1, \mathrm{~b} 1$ and $\mathrm{b} 2$ vary depending on which region the study area is located.

\subsection{Low Flow Estimation for Un-gauged Site}

No historical record of stream flow being done before at the study area. The location of Rompin itself is affected by tidal flow. In this study, we used the coefficient of Central Pahang as coefficient to calculate in the equation. The result coefficient used are a1 $=1.676 \times 10-16, \mathrm{~b} 1=1.196$, and $\mathrm{b} 2=$ 3.587. Therefore, the relevant equation for can be written as,

$\mathrm{MAM}=\mathrm{a} 1(\mathrm{AREA})^{\mathrm{b}} 1(\mathrm{MAR})^{\mathrm{b} 2}$

Mean Annual Rainfall (MAR) for this area is about $2500 \mathrm{~mm}$. $Q D, T$ is obtained by multiplying the $\frac{Q_{D, T}}{M A M}$ against MAM. Values of $\frac{Q_{D, T}}{M A M}$ for ARI 10 years is 0.570 . Further, $Q 7,10$ is obtained by multiplying the 0.570 against estimated MAM.

The result of MAM for every catchment are shown as below: 
Table 1: MAM for every catchment area

\begin{tabular}{lll}
\hline Catchment & Area, $\mathrm{km}^{2}$ & MAM, $\mathrm{m}^{3} / \mathrm{s}$ \\
\hline Catchment Sg Sawak & 21.7 & 0.0284 \\
\hline Catchment Sg. Pontian & 11 & 0.0103 \\
\hline
\end{tabular}

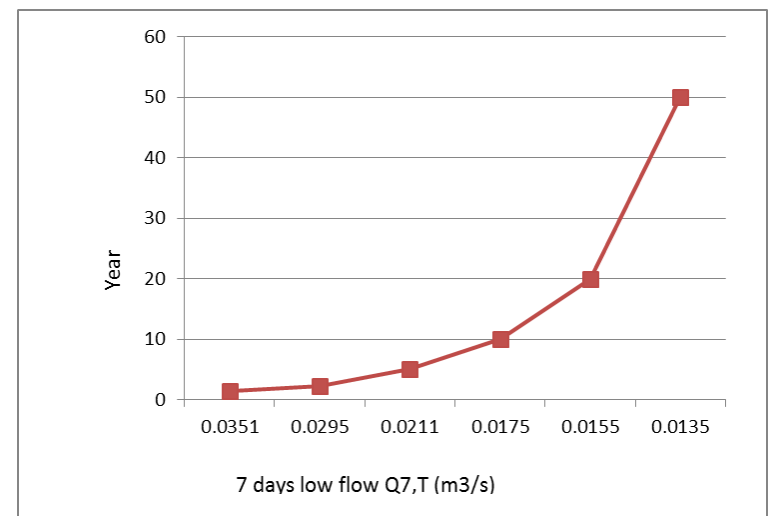

Figure 2: The 7-Days Low Flow for Catchment Sg. Sawak

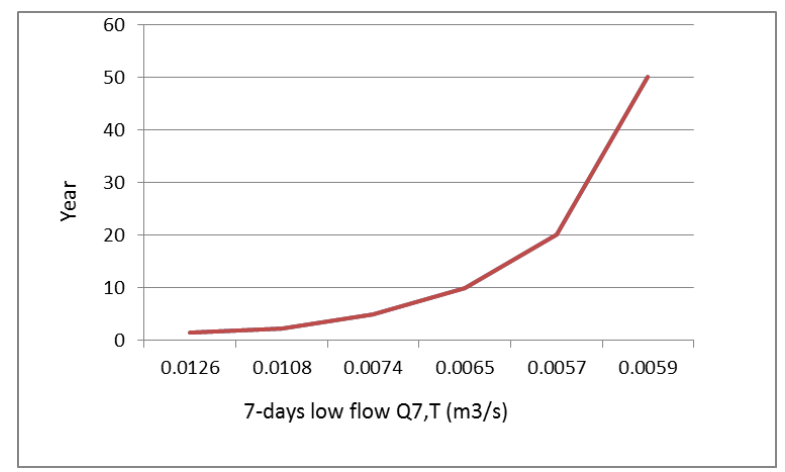

Figure 3: The 7 Days Low Flow for Catchment Sg. Pontian

Table 2: The 7-Day Low Flow Estimates for both catchments

\begin{tabular}{ll}
\hline Catchment & 7 days low flow Q7 \\
\hline Catchment Sg Sawak & $0.0179 \mathrm{~m}^{3} / \mathrm{s}$ \\
Catchment Sg. Pontian & $0.0067 \mathrm{~m}^{3} / \mathrm{s}$. \\
\hline
\end{tabular}

From the study, the result 7Q10 estimated were $0.0179 \mathrm{~m}^{3} / \mathrm{s}$ in Sg Sawak Catchment and $0.0067 \mathrm{~m}^{3} / \mathrm{s}$ in Sg. Pontian Catchment. 


\section{CONCLUSION}

In conclusion, the result of low flow is for the management of water resources. However, the selection methods in the study able to determine low flow in ungauged catchments. Maybe for further research method in prediction on low flow ungauged site can be identified by using multiple regression method or using other models that give good result and more precise.

It is therefore in advise, this area need to have continued monitoring data with more station in to order to develop of a low flow quality control for human water resources conservation. Climate change interest need to be consider in future study can be included to.

\section{REFERENCES}

[1] World Meteorological Organization - WMO, 2009. (WMO No. 168).

[2] Whitehead, P.G ., Wilby, R.L., Battarbee, R.W., Kernan, M ., and Wade, A.J.: A Review of the potential impacts of climate change on surface water quality, Hydrog.Sci. J., 54, 101$121,2009$.

[3] World Meteorological Organization. 2009. WMO-No. 1055

[4] Putri Shazlia, 2016. Water Quality Assessment of Muar River Using Environmetric Techniques and Artificial Neural Networks. ARPN Journal of Engineering and Applied Sciences. Vol.11. No.11. 1-6.

[5] Hebert, C., El-Jabi, N., and Caissie, D.: Low flow estimation for New Brunswick Rivers, Can. Tech. Rep. Fish. Aquat. Sci., 2493, 24 pp., 2003.

[6] Environmental Protection Act- EPA 1986. Management of Water Resources and Application of Hydrological Practices.

[7] Maidment, D.1993. Handbook of Hydrology. London: McGraw Hill Publisher.

[8] U.S. Environment Protection Act. 1997. United Stated.

[9] Hydrological Procedure No.12 (HP12). 1975. Magnitude and Frequency of Low Flow in Peninsulr Malaysia. Kuala Lumpur: Drainage Irrigation and Department Malaysia.

[10] Grandry, M., Gailliez, S., Grandry, M., Gailliez, S., Sohier, C., Verstraete, A. \& Degré, A. 2012. A method for low flow estimation at ungauged sites, case study in Wallonia (Belgium).Hydrol. Earth Syst.Sci. Discuss 9:11583-11614.

[11] Smakhtin, V. U.: Low flow hydrology: a review , J. Hydrol., 240, 147-186, 2001. 